\section{SMOKING MACHINES}

Smoking machines are mechanical devices for the standardized smoking of cigarettes, facilitating the determination of nicotine and condensate yields of cigarettes according to strictly controlled parameters such as puff duration, puff volume, number of puffs and butt length. The development of smoking machines dates back some 50 years. The first - a four channel smoking machine was built by Bradford, Harlan and Hammer (American Tobacco Company) in 1936 (1).

Design improvements introduced in the fifties and sixties led to the definition and standardization of certain smoking parameters which were set down in a fixed version either as recommended methods or as national and international standards (CORESTA recommended methods, DIN 10240, FTC Standard, ISO 3308) $(2,3,4,5)$.

Smoking machines consist of three basic elements: the cigarette holder, the smoke generating device and the smoke trap. There are two basic systems which meet the requirements of the current international standards (ISO 3308 and ISO 4387) and German standards (DIN ISO 3308 and DIN ISO 4387) $(7,8)$.

\section{A. The rotating system}

In this system the position of the cigarette in its holder is fixed, i.e. adjustments are made by moving the puff termination device (7). The cigarette holder of a rotating smoke ring allows smoking of one or more cigarettes, so that the smoke enters a single smoke trap.

\section{B. The linear smoking system}

The position of the puff termination device remains fixed, i.e. adjustments are made by moving the cigarette and its holder. This type of machine is available with 20 or 8 channels. Using the linear system, several cigarettes are smoked one after another into the same smoke trap.

Whereas rotating smoking machines are very widely found in Central and Eastern European countries, companies and institutes in the English-speaking world tend to prefer linear smoking systems.

In both machine types, the total particulate matter (TPM) is collected in the smoke trap. The following methods of collecting smoke particles are in general use: precipitation on electrostatic or glass fibre filters, capillary condensation, precipitation in fluids, collection in cooling traps (1). The current DIN ISO 4387 dealing with determination of TPM and nicotine-free dry particulate matter (NFDPM) of cigarettes refers to glass fibre filters for collecting smoke particles (8). At the moment efforts are being made by smoking machine manufacturers to further automate the smoking process.

The first machine smoking methods were developed and published by the Federal Trade Commission (FTC) in the USA in 1967 (4) and by CORESTA (Cooperation Center for Scientific Research Relative to Tobacco) in 1968 (2). Since that time machines and methods have

Table 1.

Conditions for standard machine smoking according to DIN ISO and FTC (6).

\begin{tabular}{|c|c|c|}
\hline $\begin{array}{c}\text { Conditioning and Smoking } \\
\text { Parameters }\end{array}$ & DIN ISO & FTC \\
\hline Conditioning temperature & $22 \pm 1^{\circ} \mathrm{C}$ & $24 \pm 1{ }^{\circ} \mathrm{C}$ \\
\hline Relative humidity (\%) & $60 \pm 2 \%$ & $60 \pm 2 \%$ \\
\hline Air velocity (mm/s) & 200 & $\begin{array}{l}\text { Minimum required to } \\
\text { remove smoke }\end{array}$ \\
\hline Puff volume (mL) & 35 & 35 \\
\hline Puff duration (s) & 2 & 2 \\
\hline Puff frequency (puff/s) & $1 / 60$ & $1 / 60$ \\
\hline Butt length & $\begin{array}{l}23 \mathrm{~mm} \text {, but not less than length of } \\
\text { filter tip }+8 \mathrm{~mm} \text { and not less than } \\
\text { overwrap length } 3 \mathrm{~mm}\end{array}$ & $\begin{array}{c}23 \mathrm{~mm} \text { or length of filter-overwrap + } \\
3 \mathrm{~mm} \\
\text { (whichever is longer) }\end{array}$ \\
\hline
\end{tabular}


Table 2.

Actual ISO and DIN ISO-Standards for sampling, machine smoking of cigarettes and nicotine determination.

ISO 3308: $\quad$ Routine analytical cigarette smoking machine - Definitions and standard conditions; September 1991 $\rightarrow$ DIN ISO 3308 since July 1992.

ISO 3400: $\quad$ Cigarettes - Determination of alkaloids in smoke condensates - Spectrometric method; April $1997 \rightarrow$ DIN ISO version in preparation.

ISO 3402: $\quad$ Tobacco and tobacco products - Atmosphere for conditioning and testing; July $1991 \rightarrow$ DIN ISO 3402 since July 1992.

ISO 4387: $\quad$ Cigarettes - Determination of total and nicotine-free dry particulate matter using a routine analytical smoking machine; September 1991 $\rightarrow$ DIN ISO 4387 since July 1992.

ISO 8243: $\quad$ Cigarettes - Sampling; September $1991 \rightarrow$ DIN ISO 8243 since July 1992.

ISO 10315: Determination of nicotine in smoke condensates - Gas-chromatographic method; August $1991 \rightarrow$ DIN ISO since July 1992.

undergone many improvements which together form the basis for current international (ISO) and national standards (e.g. DIN ISO, FTC). However, there may be differences between individual countries in defining certain parameters for machine smoking and for sample preparation (6). Thus the FTC method used in the USA differs from that of ISO or DIN ISO as regards smoking to a certain butt length, air velocity and sample preparation (see Table 1). The data obtained by these machine smoking procedures enable the consumer to compare the nicotine and "tar" yields of different brands. They are not intended to indicate the smoker's individual uptake of nicotine and "tar" (9).

Table 2 shows the international and German standards currently valid for machine smoking of cigarettes and determination of nicotine.

\section{REFERENCES}

1. De Bardeleben, M.Z., J.E. Wickham and W.F. Kuhn: The determination of tar and nicotine in cigarette smoke from an historical perspective; Recent Adv. Tob. Sci. 17 (1991) 115-48.

2. CORESTA Standard Method No. 10: Machine smoking of cigarettes, determination of crude and dry smoke condensate; CORESTA Information Bulletin 1 (1996) 24-33.
3. DIN Deutsches Institut für Normung e.V.: Untersuchung von Tabak und Tabakerzeugnissen - Maschinelles Abrauchen von Zigaretten und Bestimmung des Rauchkondensats: Anforderungen an eine analytische Rauchmaschine; DIN 10240, Beuth Verlag GmbH, Berlin, 1978.

4. FTC Federal Trade Commission: Cigarettes: Testing for tar and nicotine content; Federal Register Vol. 32, Washinton, D.C., 1967, p. 11178.

5. International Standards Organization: Cigarettes Routine analytical smoking machine - Definitions and standard conditions; ISO 3308, International Organization for Standardization, Genève, 1986.

6. Eberhardt, H.-J. and G. Scherer: Human smoking behaviour in conmparison with machine smoking methods: A summary of the five papers presented at the 1995 meeting of the CORESTA Smoke and Technology Groups in Vienna; Beitr. Tabakforsch. Int. 16 (1995) 131-140.

7. DIN Deutsches Institut für Normung e.V.: Zigaretten-Abrauchmaschine für Routineanalysen: Begriffe und Standardbedingungen; DIN ISO 3308, Beuth Verlag GmbH, Berlin, 1992.

8. DIN Deutsches Institut für Normung e.V.: Zigaretten - Bestimmung des Rohkondensats und des nikotinfreien Trockenkondensats unter Verwendung einer Abrauchmaschine für Rountineanalysen; DIN ISO 4387, Beuth Verlag GmbH, Berlin, 1992.

9. Borgerding, M.F.: The FTC method in 1997 - What alternative smoking condition(s) does the future hold; Recent. Adv. Tob. Sci. 23 (1997) 75-152. 